\title{
Energy strategy development of Azerbaijan, Turkmenistan and Uzbekistan: A Comparative Analysis $^{1}$
}

\author{
Rovshan Ibrahimov \\ Hankuk University of Foreign Studies, South Korea
}

\section{Introduction}

Azerbaijan, Uzbekistan and Turkmenistan are the three former republics of the Soviet Union, which are endowed with rich hydrocarbon resources. This factor is crucial in the development of these countries. The availability of oil and gas for any state is considered a panacea for solving economic problems and even realizing of political goals; the three countries are not an exception in this row either. Having gained independence in 1991, Azerbaijan, Uzbekistan and Turkmenistan began to actively seek ways to increase the extraction of their natural resources and markets for their sale. However, each country chose its own strategy. In general, the energy strategy of these countries can be divided into two periods: the first period, the desire to increase oil and gas production and the formation of transport routes to enter the world markets, the second period that began relatively recently, the formation of a petrochemical industrial complex to increase the effective use of energy resources and revenues from them. It is worth noting that the implementation of tasks set in the second period can be carried out in parallel with the continuation of the strategy that was formed in the first period. This article provides information on the energy strategies of Azerbaijan, Turkmenistan and Uzbekistan, on the stages of its development, common and different sides in their policies.

\footnotetext{
${ }^{1}$ This work was supported by Hankuk University of Foreign Studies Research Fund of 2018
} 
The first stage of the implementation of the energy strategy of Azerbaijan, Uzbekistan and Turkmenistan, the task of increasing oil and gas production: A comparative analysis

\section{Energy Strategy of Azerbaijan: Attracting Western Energy Companies}

Azerbaijan has been producing oil for more than 150 years, since the times of the Russian Empire. After the Soviet Union collapsed and Azerbaijan gained independence, this country, like all the former republics of the Soviet Union, faced very serious political and economic problems. At the same time, the situation was complicated due to the existing Nagorno-Karabakh conflict with Armenia, which grew into the war in the first years of independence.

To solve numerous problems, Azerbaijan decided to use its energy resources. However, in the last years of stay in the Soviet Union, oil production in the republic has significantly decreased. As for natural gas, Azerbaijan even has to buy it for domestic consumption from other republics of the Soviet Union, primarily from Turkmenistan. It should be noted that, despite the fact that Azerbaijan has been engaged in extraction of energy resources for about a century and a half, this country still possesses significant deposits of oil and gas. However, for their exploitation, the Soviet Union, and now independent Azerbaijan, did not have the necessary technologies or large finances. The resolution of this task was seen only in one: by attracting large Western energy companies. It should be noted that in case of successful resolution of this problem, Azerbaijan allowed not only its geoeconomic, but also geopolitical goals. After all, the involvement of such large companies could not do without the attention and support of the governments of the countries to which these companies belonged.

It should be noted that the negotiations of Azerbaijan with Western energy companies began in the period when this country was part of the USSR. This became possible due to the fact that on September 23, 1989, the Supreme Soviet of the Azerbaijan SSR adopted, the Constitutional Law "On sovereignty of the Azerbaijan SSR". This law formed a new legal format on the territory of the USSR, according to which the priority of Azerbaijan's own laws over the Union's was formed. Azerbaijan became the first of the republics of the former Soviet Union, to adopt this kind of law. Thus, Azerbaijan has declared its economic sovereignty, which is allowed to partially dispose of its own resources. Thus, there was a legal basis for attracting energy companies (Rovshan Ibrahimov, 2014, 95).

Already in the early 90s, Soviet Azerbaijan begins the negotiations with British Petroleum, Norwegian Statoil, and American Amoco and Unocal. As can be seen, large Western energy companies from several countries were selected to attract oil 
fields. The main subjects for negotiations were large offshore oil fields of Azeri, Chirag, Guneshli. Negotiations with these companies continued after the restoration of Azerbaijan's independence. Despite the fact that the parties were close to signing the agreement several times, on political issues that stemmed from political instability and frequent change of leadership in the country, it was signed only on September 20,1994, by the third president of the country, Heydar Aliyev.

The "Contract of the Century" was signed for 30 years and went into force on December 12, 1994. During the signing of the contract, Azerbaijan International Operating Company (AIOC) was established, a consortium of which SOCAR, British Petroleum, Pennzoil, Lukoil, Amoco, Unocal, Statoil, Ramco, McDermott, TPAO and Delta-Nimir. The composition of the consortium and the share changed from time to time, and at the moment includes SOCAR - $11.6461 \%$, BP $35.7828 \%$, Statoil - 8.5633\%, INPEX -10.9644\%, TPAO-6.75\%, Exxon Mobil 8,0006\%, ITOCU - 4,2986\%, Chevron Texaco - 11,2729\%, Amerada Hess $2,7213 \%$.

The first oil from the Chirag field was mined in November 1997. Since then, until January 2017, the consortium of companies within the framework of the "Contract of the Century", have produced 416.5 million tons of oil and 128.2 billion cubic meters of associated gas." 231.8 million tons of oil and all associated gas amount is the profit which received Azerbaijan (Azernews, 2017).

After the successful implementation of the "Contract of the Century", Azerbaijan continued to establish relations with foreign energy companies for the exploitation of other fields. It is worth noting that these relations are formed in the framework of the Production Sharing Agreement (PSA). This legal format was in the interests of Azerbaijan. Foreign companies fully ensure the implementation of the project by technical services and finance, and also assume possible risks in connection with the operation. In the event that no commercially attractive deposits of energy resources are found in the fields, the companies do not receive compensation (Fatma Babayeva, 2016).

Considering that in the early 90s Azerbaijan did not have financial resources, this propose was optimal for Azerbaijan. According to the PSA, the first stage of its implementation provides for the return of capital investment that has been made by energy companies in the development of deposits, after which revenues from the sale are distributed among Azerbaijan and companies. Until now, SOCAR, representing in PSA, has been signed more than 30 PSA with foreign energy companies. 
Among these agreements, PSA for the Shah Deniz gas offshore field which was signed on June 4, 1996 is the most important. During signing ceremony consortium consisted SOCAR (10\%), BP (25.5\%), Statoil (25.5\%), Iranian OIEC (10\%), Russian / Italian joint company LukAgip (10\%) and TPAO (9\%). Currently, after several changes, the following companies involved into consortium: SOCAR (as AzSD and SGC Upstream) (16.7\%), BP (28.8\%), Petronas (15.5\%), Iranian NICO (10\%), Russian / Italian joint company LukAgip (10\%) and TPAO (19\%) (Report, 2017).

The total reserves are estimated at 1.2 trillion $\mathrm{m}^{3}$ of natural gas (9th largest gas field in the world) and 240 million tons of gas condensate. Thus, Azerbaijan will able not only to fully cover its own needs for natural gas and to abandon its imports, but along with oil, the traditional export product of Azerbaijan, to sell it abroad. After carrying out the necessary work, the gas production from the Shah Deniz field was started on December 15, 2006. Due to the production of gas from the Shah Deniz field, Azerbaijan is primarily intended to compensate for the supply of Russian gas. Before it Azerbaijan imported annually about 5 billion $\mathrm{m}^{3}$. But Russia steadily started to increase price for export gas which was not in the interests of Azerbaijan. Azerbaijan could cover domestic demand and in addition, began to export gas to Georgia and Turkey.

Since the beginning of natural gas production on Shah Deniz field Stage 1 till January 2017, 78.4 billion $\mathrm{m}^{3}$ of gas and 19.6 million metric tons of condensate were produced. Of this amount, 43.8 billion $\mathrm{m}^{3}$ was exported to Turkey, while 5.9 billion $\mathrm{m}^{3}$ to Georgia (Report, 2017).

Along with Shah Deniz, other gas fields have been found in the Azerbaijan sector of the Caspian Sea, such as Umid (with estimated gas reserves of 200-300 billion $\mathrm{m}^{3}$ ), Babak (600 billion $\mathrm{m}^{3}$ ), Absheron (350 billion $\mathrm{m}^{3}$ of gas and 45 million ton of condensate) for which PSA has also been signed with energy companies. Thus, in the next decade, production and exports of natural gas are expected to grow.

SOCAR is the main company for oil and gas production in Azerbaijan. In addition, this company was a key player in negotiations with Western companies to develop onshore and offshore fields located in Azerbaijan. At the same time, if you consider all the agreements that were signed by SOCAR, it's possible to see a tendency that as the positions, experience and financial opportunities of state company strengthened the share of SOCAR in projects to increase. At the same time, SOCAR began to acquire additional shares in projects that were signed at an early stage and were of a political rather than an economic nature. Thus, SOCAR 
increased its share in the "Contract of the Century" and in the consortium for the development of the Shah Deniz gas field.

Thus, Azerbaijan, as her projects for the extraction of natural gas develop, will be converted into an important supplier of energy resources to the world markets. In addition, there are many more promising fields that have not yet been researched. It is worth noting that in general there are 231 prospective structures both onshore and offshore, and $38.1 \%$ on the land and $61.9 \%$ in the Caspian sector.

\section{Turkmenistan: Maximizing Neutrality}

Like Azerbaijan, Turkmenistan is a former republic of the Soviet Union, but located in Central Asia. On the initial path of the state building, Turkmenistan had similar characteristics with other former Soviet republics. As a legacy from the USSR, the country suffered an economic collapse: a reduction in GDP, hyperinflation, massive unemployment, and low payment rate. It was also necessary to transit to new forms of governance, to start building a market economy, to establish trade relations with neighboring countries. The solutions to these problems were the extraction and export of energy resources to world markets, the revenues of which were supposed to help solve economic problems. It should be noted that Turkmenistan holds the fourth place in the world for natural gas reserves after Russia, Iran and Qatar.

While in the Soviet Union, Turkmenistan specialized in the production of natural gas. Turkmenistan accounted for $70 \%$ of the known natural gas deposits in Central Asia. In 1989, 85.5 billion $\mathrm{m}^{3}$ of natural gas were produced (RPI-Research). However, in the first years after independence, the energy sector of Turkmenistan was shaken by the economic crisis and the partial loss of traditional partners in the post-Soviet space.

Immediately after independence, Turkmenistan began to form its energy economy. It should be noted that, unlike Azerbaijan, at the initial stage, Turkmenistan concentrated all the extraction in the hands of the state, without involving foreign companies. At the same time, unlike Azerbaijan, where all activities in the energy sector are concentrated in one company - SOCAR, in Turkmenistan, two different state companies are engaged in oil and natural gas production. In a word, the Turkmen national oil company Turkmenneft is engaged in oil production in the republic. In turn, Turkmengaz is responsible for the entire cycle of activities with natural gas: exploration, extraction, transportation, processing, and development of the exploration industry. In addition to these two companies, there are other state- 
owned companies, such as Turkmengeology, whose main activity is the comprehensive study and the identification and exploration of new oil, gas, solid minerals and elevated water, as well as the increase in hydrocarbon and mineral reserves. Another company, Turkmenneftegazstroy, specializes in the development of oil and gas fields, the construction of oil and gas facilities and the improvement of the management structure for this specific construction (Oilgas).

As the development and necessity of increasing the extraction of energy resources were developed, Turkmenistan realized that its own resources and potential would not suffice, and therefore foreign energy companies began to be involved. At the same time, unlike Azerbaijan, which attracted Multinational Western Companies, which are world leaders in the sector, mainly from the USA and Great Britain, Turkmenistan preferred cooperation with national companies from Asian countries. Thus, In the Caspian Sea at the Magtymguly, Diyarbekir deposits and in the perspective on Garagol-Deniz West field, oil is extracted from the Malaysian oil company Petronas. It is significant that Petronas became the second foreign company to produce oil in Turkmenistan. Previously, the only marine oil producer was the Anglo-Arab company Dragon Oil. This company since 1999 has been developing the Cheleken offshore block which includes the Dzheitune and Dzhygalybeg oil fields within the framework of PSA (Rigzone, 2009).

In the gas sector, cooperation with the Chinese national oil and gas corporation CNPC is very active. On July 17, 2007 between the State Agency for Management and Use of Hydrocarbon Resources under the President of Turkmenistan and CNPC PSA was signed for a period of 30 years. The project includes the largest in Turkmenistan Samandepe field, which was discovered in 1980. According to experts, it contains 100 billion $\mathrm{m}^{3}$ of gas and 5 million tons of gas condensate. At Samandepe field, the Chinese company commissioned dozens of old wells, and drilled new production wells with a good natural gas production rate. Another large deposit of this project is Altyn Asyr. In addition, in 2010, with the participation of CNPC, the Agayra field was discovered with estimated gas reserves of 73 billion $\mathrm{m}^{3}$. To this day, CNPC has invested about $\$ 4$ billion in this project (Rovshan Ibrahimov, 2015).

One of the largest gas fields in Turkmenistan opened in 1982 near the town of Serakhs in the Maryinsky region - Dauletabad. This field is located near the Iranian border, and its continuation is one of the largest gas fields in Iran, Khangiran. Presumed reserves of Dauletabad are about 1.2 trillion $\mathrm{m}^{3}$ (Qaya Mammadov, 2015). This field is important for the country both in terms of geopolitics and geoeconomics. 
The Yuzhny Yolotan field, later merged with another large gas field- Minar discovered in 2009, and a number of other deposits, and renamed Galkynysh. This super-giant deposit is the pearl of the gas sector of Turkmenistan. An independent audit conducted by the British company Gaffney, Cline \& Associates, revealed that 21,2 trillion $\mathrm{m}^{3}$ of gas are located in the bowels of Galkynysh, which rank second in the world in terms of reserves after South Pars gas field.(James Kilner, 2011). The total reserves of the complex together with another large Yashlar field discovered in 2008 are 26.2 trillion $\mathrm{m}^{3}$ of gas, as well as 300 million tons of oil. As follows from the above, Turkmenistan decided to approach the production of natural gas in these fields in the complex, combining them under a common legal status. As a result, in December 2009 an agreement was signed between the Turkmen government and the Chinese CNPC, South Korean Hyundai Engineering and the company from the United Arab Emirates Petrofac with the aim of developing Galkynysh (Huseyn Hasanov, 2015). The operator of development is the Turkmen state company Turkmengaz. Since that time, active industrial development of this field began.

In general, in 2014, Turkmenistan produced more than 69,3 billion $\mathrm{m}^{3}$ of natural gas, of which more than 41,6 billion $\mathrm{m}^{3}$ was exported. In 2015 , the production of natural gas in the country was to reach the level of 72,4 billion $\mathrm{m}^{3}$, but export decreased till 38,1 billion $\mathrm{m}^{3}$ (Worldview, 2017).

\section{Uzbekistan: Decreasing of Energy Resources}

The main export commodities of this Central Asian country are natural gas and cotton. Oil production today does not cover even domestic needs. To date, recoverable proven hydrocarbon reserve exceeded 2.5 billion metric tons of oil equivalents. $65 \%$ of this volume consists natural gas reserves (Global Legal Insights, 2017). Proven natural gas reserves are 3.4 trillion $\mathrm{m}^{3}$. Oil and natural gas are produced in five oil and gas regions: Ustyurt, Bukhara-Khivi, South-Western Hissar, Surkhandarya and Fergana.

The oil and gas industry of Uzbekistan accounts for about $16 \%$ of the country's GDP, and, its share is more than $20 \%$ in the revenue of the budget. Energy consumption in Uzbekistan is also high. In general, the economy of Uzbekistan is quite energy-intensive; the country is the 10th largest gas consumer in the world (Rovshan Ibrahimov (b), 2015).

In 1985, a large oil and gas condensate field Kokdumalak which is located on the border with Turkmenistan was discovered (Central Asia, 2002). This field is very 
important for the gas sector in Uzbekistan. This deposit accounts for up to $70 \%$ of the country's oil reserves. The recoverable reserves of the field are estimated at 54.3 million tons of oil, 67.4 million tons of condensate, 128 billion cubic meters of natural gas (Rovshan Ibrahimov (b), 2015).

After gaining its independence, in 1992 Uzbekistan established the state corporation of the oil and gas industry Uzbekneftegaz with the purpose of developing its subsoil for extraction of oil and gas. With a three-level vertically integrated management system. The company is the main producer of oil and gas in the country, as well as a partner in consortia with foreign companies.

An interesting development of the energy sector was observed after Uzbekistan gained independence. Unlike other countries of the former Soviet Union, whose economies rely on oil and gas production, Uzbekistan has managed to avoid a decline in the rate of oil and gas production. Moreover, for the period from 1991 to 1998, oil and condensate production increased from 2.8 million tons to a peak of 8.2 million in 1998. The main production of oil and gas condensate was provided through the exploitation of Kokdumalak (Rovshan Ibrahimov, (b) 2015).

However, the growth in production was provided with a high price. Incorrect exploitation has led to depletion of the already limited deposits in the field. In addition, it should be noted that oil production in this state was insignificant. After that there was a recession, the peak of which occurred in 2001. At that time, the average production was about 3.5 million tons of oil and gas condensate per year. In this case, the gas condensate is taken into account. However, in subsequent years in Uzbekistan, again in contrast to other former Soviet republics, there has been a decline in the production of oil and gas. This trend is irrevocable. Reserves of oil and natural gas are depleted.

The total reserves of proven oil reserves in Uzbekistan are about 594 million barrels (EIA, 2016). However, even these relatively modest reserves are located in the depths of about 100 oil, oil and gas and oil and gas condensate fields. It is expected that these reserves will be enough for oil production in the next 20 years.

Production of oil is not enough even to ensure domestic needs of the country. Uzbekistan is only half providing itself with oil. Despite the fact that for a relatively large population (about 30 million people) the annual oil consumption of the country is very modest. The difference between production and consumption is imported. At the same time, oil imports are growing every year.

A slightly different picture is seen in the natural gas production sector. In 2016, Uzbekistan produced 56,6 billion $\mathrm{m}^{3}$ of gas and was on the third place after in 
Eurasia region after Russia and Turkmenistan. (EIA,2016) There is also a drop in the production of natural gas. So, gas production in 2015 amounted to about 57,7 billion $\mathrm{m}^{3}$. (BP, 2016, 22).

Mainly gas is extracted in the regions of Gazli and Kashli. However, the figures in different sources may differ, since official statistics on the production of oil, gas condensate and natural gas in Uzbekistan are not published. It is believed that natural gas reserves in Uzbekistan will last for the next 25-30 years.

Uzbekistan is trying to increase the production of oil and gas, or at least to prevent its decline. One solution to this problem is to invite foreign energy companies with broader financial opportunities and advanced technologies. This process began in the early 2000 s.

To this end, the legislation of the republic was improved. In December 2001, the Law "On Production Sharing Agreements" was adopted, in 2002 - a new version of the Law "On Subsoil", at the legislative level, significant tax breaks were granted to foreign investors.

As a result, a number of foreign companies, such as Russian Gazprom, LUKOIL, British-Canadian company Tethys Petroleum (in 2014 the company left Uzbekistan), Chinese CNPC were involved in the projects.

Uzbekistan sees another way out of the current situation in the development of non-traditional types of hydrocarbon raw materials. Thus, the beginning of the exploitation of oil shale deposits is widely discussed in the country. In 2013, the state-owned company Uzbekneftegaz began drilling operations at the Sangrunau field in Navoi region with reserves of 357 million tons. The company hopes to increase oil production by 1 million tons per year due to this field. The total reserves of oil shale in Uzbekistan are estimated at approximately 47 billion tons located at a relatively shallow depth of $600 \mathrm{~m}$. More than $60 \%$ of the territory of Uzbekistan is considered promising for their extraction.

\section{Implementation of the second stage of the energy strategy by Azerbaijan,} Turkmenistan and Uzbekistan: Development of the petrochemical industry

\section{Azerbaijan: Formation of New Geo-Economic Goals}

After the successful implementation of the first stage of the energy strategy, according to which the exploitation of oil and gas fields and their exports to world markets was started, the main task facing Azerbaijan is to increase the efficiency of 
generating revenues in this area. It's no secret that oil and gas fields are not eternal, and eventually they will run out completely. There has already been a drop in oil production. That is why it was decided to create a petrochemical complex with the goal of increasing revenues through the sale of finished products, rather than raw materials. In this regard, a new concept was adopted, according to which it is expected to implement the second stage of Azerbaijan's energy strategy.

It is worth noting that in the Soviet period there was a highly developed petrochemical complex in Azerbaijan. However, it is technically obsolete and does not meet modern requirements. For this reason, many enterprises ceased to exist.

As for the operating enterprises, SOCAR has two oil refineries and one gas distribution plant on the territory of Azerbaijan-Azerneftyanajag, Azerneftyagh Oil Refinery and The Gas Processing Plant. All the plants were built in the times of the Soviet Union with the goal of processing crude oil and gas into finished products. In general, the production of plants was for the domestic market. However, part of the product is also exported. The biggest Azerneftyanajag refinery or which was renamed after 2004 as Heydar Aliyev Baku Oil Refinery is processing Azerbaijan oil and produce different petroleum products such as automotive gasoline, aviation kerosene, diesel fuel, black oil, petroleum coke. In addition to the fact that the plant covers the needs of the domestic market, $45 \%$ of its petroleum products are exported (Official site of SOCAR, (b)).

In 2014, SOCAR announced the liquidation of Azneftyagh by merging it with Heydar Aliyev Baku Oil Refinery. This measure was taken to improve and optimize the structure of the company itself, as well as organizing the management of the refinery process from a single center (Newsday.az, 2015).

Since the processing plants were built in the Soviet era (Heydar Aliyev Baku Oil Refinery was established in 1953, and Azerneftyagh Oil Refinery in 1976), the government of Azerbaijan and SOCAR plans to build a new complex, as well as upgrade existing plants. Already by 2020, Azerbaijan intends to reconstruct Baku Oil Refinery. Then the processing capacity will reach up to 7.5 million tons of oil a year (Azernews, 2016).

An important project implemented by SOCAR is the Oil and Gas Processing Complex (OGPC), the construction of which will be realized in 60 kilometers of Baku near Sangachal Terminal, hub of the main oil and gas transit pipelines. The total amount of the project is estimated at $\$ 17.1$ billion and it is expected that the first stage of this complex will start functioning in 2023 (Azernews, 2016). Thus, the construction of a modern complex will also allow the organization of production outside of the large cities located on the Absheron Peninsula. Since, 
Rovshan Ibrahimov

after the complex starts its work the corresponding production in Baku and Sumgait will be demolished (Official site of SOCAR (b)).

Without a doubt, this will also improve the ecological situation in these two large cities and will also allow the redistribution of the population, which at the moment is mainly migrating to these cities.

Within the project is also expected construction of Gas Processing Plant, Oil Refinery, and Petrochemical Plant. It is expected that a new oil refinery will have a capacity of 10 million tons per year while Gas Processing Plant with have annual capacity of 10 billion $\mathrm{m}^{3}$, at the same time Petrochemical Plant will have annual capacity of 1.7 million tons of finished products. The construction of a petrochemical complex will allow Azerbaijan to increase and diversify the export of industrial products. Produced products will be sold not only in the domestic market, which is in great demand for petrochemical products, many of which are currently imported. Since the Azerbaijan market is not voluminous, the bulk of the products produced by this complex, among which polyethylene, polypropylene and butadiene, which is in high demand in the world markets, will be exported (Gulgiz Dadashova, 2014).

To this end, SOCAR conducted a tender to select a company that will manage the construction of the complex. As a result of the tender, this company became Fluor Corporation (Reuters, 2015). In addition, a sub-contract was signed between SOCAR and Technip SA with a view to delivering technology licensing and design work for this processing and petrochemical complex (OGJ, 2017). It should be noted that the increase in the powers and spheres of activity of SOCAR is of an evolutionary nature: as its capabilities grew, so did its tasks. In a word, by decree of the President of the Republic of Azerbaijan, in 2009 Azerigaz, and in 2010 Azerkimya state corporations were transferred under the control of SOCAR. Thus, SOCAR also integrates enterprises responsible for the distribution of natural gas in the territory of Azerbaijan (Azerigaz), as well as the production of chemical products (Azerkimya). This ensures the coordination of these sectors of the economy under the management of the state oil company, which will help prevent unwanted bureaucratic obstacles and increase the effectiveness of decision-making.

Within SOCAR, Azerikimya Production Union was established, which consists of a number of enterprises, including: an ethylene-polyethylene plant, a surfactant plant, an organic synthesis plant, a machinery maintenance plant and a chemical engineering institute. The complex produces ethylene, propylene, polypropylene, industrial isopropyl alcohol, caustic soda, chlorine, sulfuric acid, sodium carbonate and other products (Official site of SOCAR, (a)). 
Provided that Azerbaijan is a landlocked state, so access to the international markets, such as the European Union, China, where mainly the realization of Azerbaijani products is planned, (OGJ, 2017) have certain difficulties. Since, it would be difficult for Azerbaijan to compete with producers that have access to the open seas. To this end, SOCAR is trying to form its activities not only within Azerbaijan, but also beyond its borders. An important country for SOCAR activities is Turkey. SOCAR forms its strategy in this country, taking into account its activities in Azerbaijan. Thus, in 2007, SOCAR jointly with Turkish companies Turcas and Injaz alliance acquired $51 \%$ of Turkey's largest petrochemicals company Petkim Petrokimya Holding A.Ş (Petkim), paying \$2 billion 040 million for the transaction. The acquisition of this complex is of strategic importance. Petkim is a largest petrochemical complex in Turkey and its products have access to world markets. At the same time, the Turkish market itself is very significant: currently, the domestic need of Turkey's petrochemical production consists $\$ 6.1$ billion, and this demand will be growing annually by 11-12\%. At the moment, Petkim covers $25 \%$ of Turkey's petrochemical demand. Thanks to the investments to the company, SOCAR plans to increase share in the Turkish market of the chemical industry from $25 \%$ to $40 \%$ by 2023 (Azad Hasanli, 2015). At the moment, SOCAR Turkey Petrokimya A.Ş. has $51 \%$, while SOCAR Turkey Enerji A.Ş. has $1.32 \%$ of share (Newsday.az, 2017).

Thus, through the acquisition of Petkim, SOCAR has the opportunity to enter to a very promising market, and also using the traditional ties of this company, in order to have access to the third countries markets. In addition, Petkim received the status of a foreign trade company in Turkey, as a company that exports more than $\$$ 100,000 per year. This will allow the company to take advantage of various benefits from state support, such as VAT refund, receiving loans with low interest rates, state support for exports and simplified customs procedures (Kamila Aliyeva, 2017).

This circumstance confirms the further activities of SOCAR in Turkey. So, not far from the location of the Petkim complex, SOCAR completed the construction of the largest container port in Turkey, Petlim Limancilık A.Ş. (Petlim), with a capacity of 1.5 million TEU per year. In addition, in 2011, again not far from Petkim and Petlim port, SOCAR began construction of a new oil refinery (Star refinery) with capacity of production of up to 10 million tons of oil annually. The total cost of Star refinery will be more than $\$ 5$ billion. (Oil and Gas Eurasia, 2015). After the completion of the STAR, SOCAR plans to start another project in Turkey in the petrochemical sector, which will cost about $\$ 3$ billion (Sara Israfilbayova, 2017). 
Rovshan Ibrahimov

All these steps can allow solving the problem of markets for the finished products of the petrochemical complex that is being constructed in Azerbaijan. It should also be noted that SOCAR has a wide network of gas stations in Switzerland, Ukraine, Georgia and Romania, and plans to purchase stations in other countries. Thus, finished products can also be realized through these stations. It is especially important that Ukraine, Georgia and Romania littoral states on the Black Sea and SOCAR will have the opportunity to transport its products to these countries. It will be possible to do both at the expense of the Turkish port Petlim and the SOCAR-owned Georgian port of Kulevi.

Thus, the second stage of the energy strategy of SOCAR includes not only the creation of a petrochemical complex, but also the logistics centers necessary for the realization of its products.

\section{Turkmenistan: Formation of Petrochemical Industry as a Way for Solution of Geopolitical Problems}

Like Azerbaijan, Turkmenistan has concentrated on further development of its energy strategy which includes the creation of a petrochemical complex for the production of finished products. At the same time, along with the fact that, like Azerbaijan, Turkmenistan wants to increase the profitability of the energy sector, but the issue of the soonest depletion of resources is not so acute: natural gas reserves in this country are very significant. Turkmenistan has another problem that Azerbaijan has managed to successfully resolve. Turkmenistan faces a serious problem of entering to the world markets. Being a landlocked state, in the issue of transportation, Turkmenistan depends on its geographical neighbors. At the same time, her neighbors like Kazakhstan, Iran and Uzbekistan themselves are producers of gas and do not or partly need Turkmen gas, while in unstable Afghanistan, natural gas is not used. Complicating the situation is the fact that after gaining independence, the main market for Turkmen gas was Russia, which is itself the largest producer of natural gas in the world. Therefore, Russia purchased Turkmen gas not for its own market, but for the purpose of reselling it and obtaining additional profit. That was the reason that Russia offered a low price for gas, which could not suit Turkmenistan. Turkmenistan was forced to reduce, and subsequently terminate, supplies to these countries. This and other reasons associated with the transportation of gas, led to a sharp decline in the export of Turkmen gas in the 90ies. So, in 1997 Turkmenistan exported only 6.5 billion $\mathrm{m}^{3}$, while in 1998 even less - only 1.8 billion $\mathrm{m}^{3}$ : this volume of gas was exported to Iran (Ishanguly Jumayev, 2012). Subsequently, the export of gas in the northern direction was repeatedly 
restored several times and stopped. In April 2009, an explosion occurred on the Central Asia-Center pipeline, which completely suspended the export of gas from Turkmenistan to the north for several months. The explosion occurred against the backdrop of tense negotiations between Turkmenistan and Russia over the determination of the price of Turkmen gas. After that supply of Turkmen gas to Russia sufficiently decreased. Thus, in 2015, Turkmenistan exported to Russia only 4 billion $\mathrm{m}^{3}$ of gas (Eurasianet, 2016).

In December 2009, a new gas Turkmenistan-China pipeline was launched, passing through the territories of Turkmenistan, Uzbekistan, Kazakhstan and China itself. By the end of 2010, the throughput capacity of the first two lines of this gas pipeline consisted 30 billion $\mathrm{m}^{3}$ of gas per year. This export direction is developing very actively and at first glance it might seem that Turkmenistan has found an alternative to Russia. In addition, unlike Russia, China purchased this gas for its own consumption. At the end of 2014, the construction of a third line with a capacity of 25 billion $\mathrm{m}^{3}$ of gas per year was completed. In 2015, the capacity of the pipeline from Turkmenistan to China already amounted to 55 billion $\mathrm{m}^{3}$ of gas per year (Official Site of MFA of Turkmenistan). According to the agreements between the two countries; Turkmenistan pledged to supply China with 65 billion $\mathrm{m}^{3}$ of gas by the end of 2020 (Eurasianet, 2016). However, in this case, Turkmenistan again becomes dependent on one customer - China. In addition, this country is the final point of gas delivery from Turkmenistan, which does not allow diversification of supplies. This circumstance creates a new dependence on one supplier for Turkmenistan. Complicating the situation is the fact that payment for the gas delivered to China is actually completely spent on payment for the construction of the gas pipeline and other facilities built by China.

In this case, the formation of a petrochemical complex for Turkmenistan is also a policy of diversifying the supply of its energy resources to world markets. It should be noted that in the territory of Turkmenistan there are enterprises of the petrochemical complex, preserved since the times of the Soviet Union. The most important of these enterprises is the oldest oil refinery in the country - the Turkmenbashi (formerly Krasnovodsk) refinery. This plant was built in 1943 and is located in the port city of Turkmenbashi on the shore of the Caspian Sea. After the country gained independence, Turkmenistan decided to reconstruct it. Enterprise is a complex of oil refineries. The total production capacity of this complex is 9 million tons of oil per year. The depth of oil refining reaches $85 \%$, which is a high index in the world. The complex specializes in the production of gasoline, aviation and technical kerosene, jet and diesel fuel, fuel oil, lubricating oils. The production of polypropylene, liquefied gas and other products, which is used both 
domestically and exported to the world markets, is also mastered (Rovshan Ibrahimov, 2016(a)).

In addition, in the east of Turkmenistan, in the Chardzhou region there is a Seydi Oil Refinery, with a processing capacity of 6 million tons of oil per year. The company specializes in the processing of primary oil, the production of gasoline, kerosene, fuel oil, diesel and other petroleum products (Neftegas, 2016). In addition, in the city of Seydi is preparing for the construction of an oil and gas chemical complex with a processing capacity of 3 million tons of oil and 3 billion $\mathrm{m}^{3}$ of gas per year. With the aim of exporting finished products, the Seydi Oil Refinery uses the Pelvert oil loading terminal, as well as a terminal for the reception, storage and sale of petroleum products in the Atamyrat city. Another terminal with a capacity of 540,000 tons of petroleum products per year is being built at the customs terminal of Ymamnazar, located in the southeast of the Lebap velayat (region) (Rovshan Ibrahmov (a)).

Among the new enterprises that are currently being built in Turkmenistan, it is possible to note the gas processing complex, which is being built on the shore of the Caspian Sea near the village of Kiyanly. It includes a plant for the purification of natural gas with a capacity of 5 billion $\mathrm{m}^{3}$ of natural gas and 2.4 million tons of gas condensate a year, a workshop for the assembly of offshore structures and a residential campus for personnel. This plant mainly processes natural gas extracted from the gas fields of offshore Block 1 by the Malaysian company Petronas (Vitaly Komarov, 2017). The gas processing plant also includes offshore platforms, $73 \mathrm{~km}$ of offshore pipelines, a complex of natural gas processing facilities, storage facilities and a remote moorage for the export of gas condensate.

In addition, Turkmenistan pays great attention to the deep processing of energy resources and the manufacture of various products from it. In 2014, a modern gaschemical complex for the production of polyethylene and polypropylene was laid in the village of Kiyanly. The project, worth about $\$ 3.5$ billion, is being implemented jointly with the Japanese company Toyo Engineering and the South Korean companies LG and Hyundai Engineering. It is expected that the plant will produce 386,000 tons of polyethylene and 81,000 tons of polypropylene per year (Export.gov, 2016).

Large Gas Processing Plants was built on the right bank of the Amu Darya River. The Chinese company CNPC in 2009 built a gas cleaning plant at the Samandepe field with a capacity of 5.5 billion $\mathrm{m}^{3}$ per year. It is expected that in 2016 the volume of natural gas processing at this plant will be brought up to 8 billion cubic meters per year. Another gas processing plant Bagtyyarlyk was also built by CNPC 
in 2014. It provides natural gas to the Turkmenistan-China gas pipeline. The given enterprise constructed on a deposit Altyn asyr, began to make 17 million $\mathrm{m}^{3}$ of a commodity gas of high quality a day. In general, the plant is designed to process 9 billion $\mathrm{m}^{3}$ of gas per year (Rovshan Ibrahimov, 2016 (a)).

Another facility is currently under construction in Ovadandepe together with the Japanese company Kawasaki, the Turkish Rönesans Holding and the Danish Haldor Topsøe. This will be the world's first gasoline production plant from natural gas. This plant will process up to 1 billion 785 million $\mathrm{m}^{3}$ of natural gas and produce 600,000 tons of gasoline that meet the Euro-5 standard per day. The total cost of the project is $\$ 1$ billion 700 million (Rovshan Ibrahimov, 2016 (a)).

As it seen Turkmenistan actively involved into the process of foundation own petrochemical complex. It's seems that this process will be continued.

\section{Uzbekistan: Substitution of Energy Depletion with More Effective Use}

Like Azerbaijan and Turkmenistan, Uzbekistan pays much attention to the development of the petrochemical complex. At the same time, as in the case of the first two countries, Uzbekistan is engaged both in the modernization of existing enterprises and in the construction of new plants. At the same time, foreign companies are actively involved in this process.

In a word, the Fergana Oil Refinery, which was built in the Soviet times in 1959, has been reconstructed. Reconstruction was carried out by Japanese companies Mitsui and Toyo Engineering (Official site of Uzneftegas). It should be noted that the main problem with the processing of oil and gas in Uzbekistan is the high sulfur content. In 1995, the plant switched to the processing of local raw materials with a high content of sulfur compounds, the plant had to preserve the range and quality of previously produced products in order to compete in the world market. Thanks to the refurbishment of the plant in the produced oil products, it was possible to reduce the sulfur content. Sulfur itself is also in demand in the market.

The plant produces about 60 types of petroleum products. The design capacity of the processing plant is 5.5 million tons of oil per year. In 1998, the Ferghana Oil Refinery established a joint venture with Texaco Holding Incorporated to produce high-quality lubricating oils.

In addition to the reconstruction of the Fergana Oil Refinery, after the acquisition of independence in 1997, the Bukhara Oil Refinery was built. A consortium led by the French company Technip participated in its construction, when the country had 
an increase in oil production, during the upswing of production at the Kokdumalak field. This enterprise produces high-quality grades of gasoline, diesel fuel and aviation kerosene. Totally refinery produces 10 types of products. The designed capacity of processing this plant is 2.5 million tons of gas condensate per year (Rovshan Ibrahimov, 2016 (b)).

It is worth noting that these companies are unprofitable. First of all, due to a shortage of raw materials, all refineries cannot operate at full capacity. So, in 2013, the total net loss of the Ferghana Oil Refinery amounted to 224.5 billion soums ${ }^{1}$, Bukhara Oil Refinery - 226.8 billion soums. The load level of the Ferghana Oil Refinery in 2013 was only $25.9 \%$. The situation at Bukhara Refinery is better-the workload was $64.4 \%$. In this connection, the government of Uzbekistan is carrying out a number of measures for the recovery of these unprofitable enterprises (Trend, 2014).

Despite the shortage of raw materials for these companies, in 2005, when the oil production crisis was already apparent, Uzbekneftegaz, in partnership with Russian company Petarmaruz, in, Surkhandarya region commissioned the Dzharkurgan oil refinery. Compared to the three above-mentioned enterprises, this refinery is relatively small and is able to process up to 130,000 tons of oil per year and receive gasoline, paraffin and bitumen. The raw materials for this plant are hydrocarbons from the fields Kakaydi, Lalmikor, Mirschodi, Uchkizil, Khovdak located on the territory of the region.

One of the enterprises for gas processing is the Mubarek Gas Processing Plant. This plant is a subsidiary of Uzneftegazdobycha and is one of the world's largest enterprises of this profile. At present, the production capacity of the plant is about 30 billion $\mathrm{m}^{3}$ of natural gas and produces more than 570 thousand tons of gas condensate per year. In addition to gas condensate, the plant produces liquefied hydrocarbon gases and sulfur.

Another gas processing enterprise in the territory of Uzbekistan is the Shurtan Gas Processing Plant, which, like the Mubarek GPP, belongs to the Uzneftegazdobycha. The annual capacity of this plant is 20 billion $\mathrm{m}^{3}$ of gas. At the plant there are 4 propane-butane mixture plants. The plant is capable of producing 104 thousand tons of liquefied gas with a separation of 56 thousand tons of propane, 48 thousand tons of butane, and 44 thousand tons of gasoline stable gasoline (Rovshan Ibrahimov (2016 (b)).

\footnotetext{
${ }^{1}$ Uzbek national currency
} 
The enterprise of the gas sector is the Shurtan Gas and Chemical Complex. This complex is engaged in the processing of natural gas with the production of ethylene, comonomer and polyethylene. More than $60 \%$ of the produced polyethylene is exported.

In accordance with the course on in-depth processing of raw materials, Uzbekistan together with a consortium of Korean companies is implementing a project to build the largest in Central Asia Ustyurt Gas Chemical Complex on the basis of the Surgil deposit. The designed capacity of the enterprise will allow processing 4 billion $\mathrm{m}^{3}$ of natural gas in order to produce 362,000 tons of polyethylene and 83,000 tons of polypropylene, as well as 100,000 tons of pyrolysis gasoline.

In addition, in 2009, Uzbekneftegaz, in partnership with the South African company Sasol and the Malaysian Petronas, is promoting a construction project on the basis of the Shurtan gas chemical complex, a processing facility with a capacity of 3.5 billion $\mathrm{m}^{3}$, which can produce 672,000 tons of diesel fuel, 278,000 tons of jet fuel, 361 thousand tons of naphtha and 63 thousand tons of liquefied gas per year. This plant can become the leader of the world energy market for the production of high-quality fuel and other products.

Another project is implemented by South Korean Hyundai Engineering \& Construction, which is engaged in the construction of the technological part of the plant for the production of synthetic fuel in the Kashkadarya region in the south of Uzbekistan. The plant will process 3.5 billion $\mathrm{m}^{3}$ of gas and produce 864 thousand tons of diesel fuel, 304 thousand tons of aviation kerosene, 395,000 tons of naphtha and 11.2 thousand tons of liquefied gas per year (Rovshan Ibrahimov (2016 (b)).

Uzbekistan has actively construct own petrochemical complex. One of the problem with which this state can be faced is scarcity of oil and gas which need for refining and production of final products.

\section{Comparative analysis of the energy strategy of the three countries: Common features and differences}

Three former Soviet republics, Azerbaijan, Uzbekistan and Turkmenistan, after gaining independence faced the same problems in the economic sphere. It was necessary in the shortest time to stop the reduction in GDP and ensure a transition from a planned economy to a market economy. For these countries, the main trump card for the realization of this goal was the availability of energy resources. 
Therefore, it was necessary to increase the production of oil and gas in order to generate income.

At the same time, each country has approached the solution of this problem differently. In short, Azerbaijan, which at that time was producing oil, through which it was possible to cover only the domestic needs of the country, to ensure production and increase production, for this country there was only one right decision: the invitation of Western energy companies. Without the necessary finance and technology, Azerbaijan was not able to independently produce oil and gas in large fields located in the Caspian Sea. At the same time, inviting Western companies, Azerbaijan allowed not only economic, but also geopolitical tasks. It was necessary to ensure the balancing of the main forces of the international system, but for this, first of all, it was necessary to attract them.

As for Turkmenistan and Uzbekistan, these countries have chosen a different version of the energy strategy for their countries. So, both countries in the early 90 's in the production of oil and gas completely relied on their own internal capabilities. National companies were engaged in the production and distribution of energy resources. Paradoxically, this approach of both countries was also based on the desire to reduce the possible dependence on the Great Power. However, if in the case of Azerbaijan, this country used its resource to attract as many international energy companies as possible from different Great States, in order to attract their attention to Azerbaijan and the South Caucasus. After the number of actors - Great Powers interests in the region increased, it would be possible to form a successful balanced policy, having the ability to maneuver and keep all of these actors at an equal distance. This was also the policy of geographic diversification of Azerbaijan's transport routes, as a result of which a number of export pipelines were built.

Turkmenistan and Uzbekistan have chosen a different path. In a word, these countries initially chose a policy of closeness, preventing the presence of any Great Powers within their territories. This position of Turkmenistan was reflected in the announcement of a foreign policy course, which is a permanent neutrality of the country. As for Uzbekistan, this country also does not burden itself with the duties of stable political relations with any of the Great Powers, periodically changing the foreign policy in a polar way, repeatedly entering and leaving her membership in the regional organizations, mainly pro-Russian ones. However, these countries, unlike Azerbaijan, had an opportunity for independent development, since those deposits that were developed in the Soviet era did not require large additional financial investments or technologies. Only as the deposits began to deplete, Turkmenistan and Uzbekistan began to attract international energy companies to 
exploit existing and new fields. At the same time, both countries in this plan acted fairly selectively, working with companies, governments, which, they think, would not put conditions on the formed regimes in these countries and would not interfere in the internal affairs of countries.

Since the beginning of 2010, all three countries of the former Soviet Union have begun to consider the possibilities for further development of the energy strategy. The most significant in the new strategy for Azerbaijan, Turkmenistan and Uzbekistan is the creation of a petrochemical complex with the aim of more efficient use of its energy resources, as well as an increase in their income. It's no secret that the sale of finished products at times brings more revenue.

After gaining independence in the 1990s, these countries did not have the opportunity to create new enterprises or reform those that inherited. The petrochemical products produced in these countries, due to outdated technologies, could not compete in international markets. Only a limited number of petrochemical products produced in these countries were sold on international markets. The situation became complicated before that it was impossible to sell these products on the domestic market either. The products produced in these countries could not compete with analogues produced abroad. As a result, many enterprises closed down or ceased to exist. Only after all three states began to receive income these states started to think about recovering their industrial capacity. Despite the fact that Turkmenistan built new export pipelines to Iran (two pipelines were built: the Korpeje-Kordkuy pipeline was put into operation in 1997 , while the Dauletabad-Sarakhs-Khangiran pipeline was opened in 2010) and China (In 2009 Central Asia-China gas pipeline was built), these directions also did not allow diversifying transport corridors (Official Site of MFA of Turkmenistan).

Iran acquires very limited volumes of gas, while deliveries of up to 3 billion $\mathrm{m}^{3}$ of gas are paid by Iran barter and only if Turkmenistan exports more, the rest is paid by Iran with money. In addition, disputes between the two countries over the payment of Turkmen gas are regularly happen. Thus, because Iran didn't pay for imported between 2007-2008 gas (As Turkmenistan claimed but Iran is partly agreed), Turkmenistan cut gas supplies to Iran in January 2017 (EurasiaDaily, 2017). As for China, at the moment virtually all Turkmen gas is exported to this country. Thus, Turkmenistan again depends on supplies in one direction, and not providing diversification of export routes. Attempts to create new transport routes, such as the Trans-Caspian gas pipeline for the export of Turkmen gas to Azerbaijan and further to Europe, and TAPI (Turkmenistan-Afghanistan-Pakistan-India gas pipeline), have still not been successful for geopolitical reasons. Russia and Iran 
are against the Trans-Caspian gas pipeline, while the implementation of TAPI is impossible due to instability in the region.

In this case, Turkmenistan is considering the possibility instead of exporting raw materials, producing finished products and exporting it. This would allow for the diversification of modes of transport, whereby finished products could be supplied to world markets. In addition, Turkmenistan badly needs currency, for the purchase of basic consumer goods. At the moment, the export of large volumes of gas to China does not provide this country with sufficient volumes of currency, since basically the income from gas is used to repay the loan to China, to the country's constructed export gas pipeline and other enterprises in Turkmenistan. On average, in 2016, China purchased Turkmen gas for $\$ 185$ per 1,000 cubic meters (EurasiaDaily, 2017).

In the case of Uzbekistan, the beginning of the formation of industry in the energy sector lies in the fact that the oil and gas fields in this country have become depleted. Uzbekistan has already turned into a country importing oil and oil products, although until recently it has fully provided itself with this product and even exported it. It is expected that in the next twenty years, existing gas fields will also be depleted. If no new major energy deposits are discovered, then this country will, in about twenty years, also import natural gas. In this case, Uzbekistan adheres to the strategy of maximizing revenues from the remaining energy resources, in the given case the production and sale of finished energy products.

All three countries are at the stage of implementing their new strategy. Since the beginning of the production of finished products is not the ultimate goal of this strategy, it is also important where and how this product will be implemented. In the case of Uzbekistan, it can also be noted its powerful domestic market, with a population of more than 30 million people and continuing to grow rapidly. However, in any case, the key here will be the opportunity to exit and compete in international markets. In this case, the formation of new transport routes to world markets is the main task for all three countries. All three countries actively participate in the implementation of regional projects, such as the transport program of the EU TRACECA, the joint initiative of Russia and Iran, the NorthSouth project, as well as the initiative implemented by China - "One belt and one way." In addition, Azerbaijan is actively implementing such transport projects as the railway, Baku-Tbilisi-Kars, which will connect Azerbaijan in the railway of Turkey, and then Europe. Another project is the implementation of sea shipping through the Caspian Sea to the Kazakh and Turkmen ports. Through this, rail transportation will be possible between China and Europe, via the Baku-TbilisiCeyhan railway. 
It is worth noting that all three countries are turning into competitors, regarding the sale of their products on the world market. However, there is also a geographical diversification of markets, directly related to the formation of transport routes. Thus, the main market for the realization of finished products for Azerbaijan will be Turkey, Russia, as well as the countries of Europe and the Mediterranean basin. At that time, as for Turkmenistan and Uzbekistan, it will be China. Therefore, a thorough study of the needs of these markets, factors affecting pricing and the possibility of offering competitive products is necessary.

\section{Conclusion}

Azerbaijan, Turkmenistan and Uzbekistan are the three former Soviet republics, which have a relatively equal fate. All three countries gained independence in 1991, and the availability of energy resources was the basis for the realization of their political and economic tasks. All three countries formed their energy strategy in accordance with the realities they faced after gaining independence. Therefore, there are similarities in the formation of their energy strategies, as well as differences. Here an important role was played by the geographical location, the political situation in the country, and economic opportunities. As a result, differences in these factors have influenced the formation of relatively different strategies for the implementation of their energy projects in these three countries.

According to the results of the first stage of implementation of the energy strategy, which each country pursued in its own way, Azerbaijan, Turkmenistan and Uzbekistan, all three countries moved to a new stage of development of this sectorthe formation of their own industrial potential. The process is the result of evolutionary practical development in the field of development, exploitation of oil and gas fields, and their export to world markets. The tasks set in the first stage of the energy strategy were partially or fully resolved. As a result, new tasks appeared that simultaneously came from both the results of the first stage of the strategy and the need for further steps. The degree of success of the implementation of the second stage of the energy strategy will depend on how far each of the countries can effectively and competently form its industrial complex in the energy sector, will be able to ensure uninterrupted entry into foreign markets and compete on them. 


\section{References and Notes:}

Azad Hasanli, (12.05.2015), SOCAR Plans to Increase Petkim's Share in Turkish Market, Retrieved November 17, 2016 from https://en.trend.az/business/energy/2393912.html. Azernews, (12.05.2016), Azerneftyag Refinery to be Demolished in 2018, Retrieved December 7, 2016 from https://www.azernews.az/oil_and_gas/96495.html.

Azernews, (18.01.2017), SOCAR Reveals Oil \& Gas Production Volumes, Retrieved June 11, 2017 from http://www.azernews.az/oil and gas/107710.html

BP, (June 2016), World Statistical Review of World Energy, Retrieved March 15, 2017 from https://www.bp.com/content/dam/bp/pdf/energy-economics/statistical-review2016/bp-statistical-review-of-world-energy-2016-full-report.pdf.

Central Asia, (31.05.2002), "Жахон" - история нефтедобычи Узбекистана в фактах и цифрах, Retrieved March 17, 2017 from http://www.centrasia.ru/newsA.php? $\underline{\mathrm{st}=1022791920 .}$.

EIA, (2016), Uzbekistan, Retrieved March 17, 2017 from https://www.eia.gov/beta/ international/analysis.cfm?iso=UZB.

EurasiaDaily, (6.01.2017), Газовый шантаж Ашхабада не срабатывает: Туркмения теряет Иран?, Retrieved February 20, 2017 from https://eadaily.com/ru/ news/2017/01/06/gazovyy-shantazh-ashhabada-ne-srabatyvaet-turkmeniya-teryaetiran.

Eurasianet, (4.01.2016), Turkmenistan: Russia Suspends Gas Supplies, Retrieved February 18, 2017 from http://www.eurasianet.org/node/76676.

Export.gov, (15.08.2016), Turkmenistan - Oil and Natural Gas Refining, Retrieved February 20, 2017 from https://www.export.gov/article?id=Turkmenistan-Oil-andNatural-Gas-Refining.

Fatma Babayeva, (10.09.2016), The Nature of Product Sharing Agreements in Azerbaijan, Energy Journal, Retrieved December 18, 2016 from https://enerpojournal.com/ 2016/09/10/the-nature-of-product-sharing-agreements-in-azerbaijan/.

Global Legal Insights, (2017), Uzbekistan, Energy Retrieved June 23, 2017 from https://www.globallegalinsights.com/practice-areas/energy/global-legal-insights--energy-5th-ed./uzbekistan.

Gulgiz Dadashova, (20.11.2014), Azerbaijan to Launch New Gas Processing, Petrochemical Plants in 2020, Retrieved December 19, 2016 from http://www.azernews.az/oil_and_gas/73525.html.

Heydar Aliyev Baku Oil Refinery, Official site of SOCAR, Retrieved December 18, 2016 from http://www.socar.az/socar/en/activities/refining/heydar-aliyev-baku-oil-refinery.

Huseyn Hasanov, (27.11.2015), Turkmenistan may expand Galkynysh gas field development, Retrieved February 20, 2017 from https://en.trend.az/business/ economy/2461806.html.

Ishanguly Jumayev, (2012), Foreign Trade of Turkmenistan: Trends, Problems and Prospects, Graduate School of Development, Institute of Public Policy and Administration University of Central Asia, Working Paper, No11, 8. 
James Kilner, (11.10.2011), Turkmenistan Holds World's Second Largest Gas Field, Retrieved February 16, 2017 from http://www.telegraph.co.uk/news/worldnews/ asia/turkmenistan/8820509/Turkmenistan-holds-worlds-second-largest-gas-field.html.

Kamila Aliyeva, (21.07.2017), Petkim's Petrochemical Complex Gains Status of Foreign Trade Company, Retrieved July 24, 2017 from https://www.azernews.az/region/n $116550 . \mathrm{html}$.

Neftegas, (8.08.2016), The Large-scale Project at Seydi Oil Refinery in Turkmenistan Approaches completion, Retrieved February 23, 2017 from http://neftegaz.ru/en/news/ view/151928-The-large-scale-project-at-Seydi-Oil-Refinery-in-Turkmenistanapproaches-completion.

Newsday.az, (22.06.2015), Нефтепереработка в Азербайджане - где, как и сколько?, Retrieved January 22, 2016 from http://news.day.az/economy/590101.html.

Newsday.az, (21.07.2017), Рetkim Получил Статус Внешнеторговой Компании, Retrieved July 24, 2017 from https://news.day.az/economy/916832.html.

Official Site of MFA of Turkmenistan, The Main Gas Pipelines of Turkmenistan, Retrieved June 25, 2017 from http://www.mfa.gov.tm/en/articles/84.

Official site of SOCAR (a), Azerikimya Production Union, Retrieved January 5, 2017 from http://socar.az/socar/en/company/organization/azerikimya-production-union.

Official Site of SOCAR (b), Oil and Gas Processing and Petrochemical Complex, Retrieved January 5, 2017 from http://www.socar.az/socar/en/new-projects/menu/oil-and-gasprocessing-and-petrochemical-complex

Official site of Uzneftegas, Fergana Oil Refinery, Retrieved July 18, 2017 from http://www.uzneftegaz.uz/en/press_center/photostock/2016/04/15/fnzp.

Oil and Gas in Eurasia, (20.03.2015), Another Refinery to be Built in Turkey, Retrieved July 24, 2017 from https://www.oilandgaseurasia.com/en/news/another-refinery-bebuilt-turkey

OilGas, Государственный концерн "Туркменнефть", Retrieved February 25, 2017 from http://www.oilgas.gov.tm/m/page/page/26

OGJ, SOCAR Lets Contract for Grassroots Gas, Petchem Complex, Retrieved July 18, 2017 from http://www.ogj.com/articles/2017/01/socar-lets-contract-for-grassrootsgas-petchem-complex.html.

Qaya Mammadov, (12.07.2015), Turkmenistan Positions Itself as Eurasian Natural Gas Power, Retrieved February 21, 2017 from http://www.ogj.com/articles/print/volume113/issue-12/transportation/turkmenistan-positions-itself-as-eurasian-natural-gaspower.html.

Report, 1(8.01.2017), So far 44 bln Cubic Meters of "Shah Deniz" Gas Transported to Turkey, Retrieved July18, 2017 from https://report.az/en/energy/44-bln-cubic-metersof-shah-deniz-gas-transported-to-turkey-so-far/.

Rigzone, (10.02.2009), Dragon Oil Encouraged by Cheleken Reserves Offshore Turkmenistan, Retrieved February 24, 2017 from http://www.rigzone.com/news/ oil_ gas/a/72741/dragon_oil_encouraged_by_cheleken_reserves_offshore_turkmenistan.

Reuters, (30.03.2015), Fluor to Manage Azeri Petrochemical Plant Construction, Retrieved December 22, 2017 from http://www.reuters.com/article/2015/03/30/azerbaijan-socarplant-idUSL6N0WW2E220150330. 
Rovshan Ibrahimov, (2014), The Importance of the Caspian Sea to Azerbaijan,The Caspain Sea at the Crossroad: Geopilitical, Geo-Strategic and Geoeconomic Analysis, ed. Carlo Frappi \& Azad Garibov, ISPI, SAM, EGEA, Milano, 95.

Rovshan Ibrahimov (2015, (a)), Power Resource Sector of Turkmenistan: Expectations and Prospects, Retrieved February 20, 2017 from http://cabar.asia/en/cabar-asia-powerresource-sector-of-turkmenistan-expectations-and-prospects/.

Rovshan Ibrahimov (2015, (b)), The Current Situation and Future of the Oil and Gas Sector in Uzbekistan, Retrieved March 5, 2017 from http://cabar.asia/en/rovshan-ibrahimovthe-current-situation-and-future-of-the-oil-and-gas-sector-in-uzbekistan/?print=1.

RPI-Research, Oil and Gas Industry in Turkmenistan, Retrieved February 25, 2017 from http://www.rpi-research.com/content/Sample_OG_Turkmenistan_eng.pdf, 5.

Sara Israfilbayova, (20.07.2017), SOCAR Plans to Implement Second Petrochemical Project in Turkey, Retrieved July 24, 2017 from https://www.azernews.az/ oil_and_gas/116511.html.

Savalan Suleymanli (2018), Common Challenges in Public Sector Performance Measurement in Post-Soviet Countries - Remedies Taken to Escape from the Soviet Legacy .Khazar Journal of Humanities and Social Sciences, Baku, Azerbaijan, Volume 21 № 1 2018, pp.23-33

Trend, (20.06.2014), Узбекистан Утвердил "Дорожные Карты" По ФинансовоЭкономическому Оздоровлению Двух НПЗ, Retrieved April 5, 2017 from http://www.trend.az/business/energy/2287210.html.

Vitaly Komarov, (2.03.2017), Record Daily Natural Gas Production is Achieved by Petronas Carigali (Turkmenistan) Sdn Bhd in the Last Year, Retrieved July 23, 2017 from http://turkmenistan.gov.tm/_eng/?id=7811.

Worldview, (13.02.2017), A New Customer for Turkmen Natural Gas, Retrieved July 23, 2017 from https://worldview.stratfor.com/image/new-customer-turkmen-natural-gas 


\title{
Summary
}

\section{Energy strategy development of Azerbaijan, Turkmenistan and Uzbekistan: A Comparative Analysis}

\author{
Rovshan Ibrahimov \\ Hankuk University of Foreign Studies, South Korea
}

\begin{abstract}
Azerbaijan, Uzbekistan and Turkmenistan are three post-Soviet countries, which are in varying degrees rich of energy resources. After gaining independence, oil and gas wealth were the main resources for overcoming acute economic stagnation, and later the formation of the economy itself in all of these countries. Even today, the energy sector is form base and essential in their economies.

As from the declaration of independence of these three countries already twentyseven years has passed, the energy strategy has become diversified and differ from each other. This is due to many factors, both internal and external. What factor affected this phenomenon will be explained in this article.

Also in his article will provide information on the development of the energy sector in Azerbaijan, Uzbekistan and Turkmenistan, from the moment they gain independence until today. The specifics of the energy strategy development in each country will be highlighted and further a comparative analysis will be conducted, according to which common points and differences between these former republics of the Soviet Union will be determined. This will allow considering the prospect of further development of the energy sector both: in these countries and in other countries, whose economy is also mainly based on the energy sector.
\end{abstract}

Key words: Azerbaijan, Uzbekistan, Turkmenistan, Energy sector, Oil, Gas 